\title{
Roseiflexus castenholzii gen. nov., sp. nov., a thermophilic, filamentous, photosynthetic bacterium that lacks chlorosomes
}

\footnotetext{
${ }^{1}$ Research Institute of Biological Resources, National Institute of Advanced Industrial Science and Technology (AIST), Tsukuba Central 6, 1-1-1 Higashi, Tsukuba 305-8566, Japan

2 Biological Laboratory, Nippon Medical School, Kawasaki 211-0063, Japan

3 Department of Biology, Tokyo Metropolitan University, Hachioji 192-0307, Japan
}

\author{
Satoshi Hanada, ${ }^{1}$ Shinichi Takaichi, ${ }^{2}$ Katsumi Matsuura ${ }^{3}$ \\ and Kazunori Nakamura ${ }^{1}$ \\ Author for correspondence: Satoshi Hanada. Tel: +81298 61 6590. Fax: +81298616587. \\ e-mail: s-hanada@aist.go.jp
}

\begin{abstract}
A novel thermophilic, photosynthetic bacterium, designated strain $\mathrm{HLO8}^{\top}$, was isolated from a bacterial mat in a Japanese hot spring. Morphologically, the isolate was an unbranched multicellular filament with a cell diameter of 0.8-1.0 $\mu \mathrm{m}$. The bacterium was red to reddish-brown in colour and formed a distinct red bacterial mat in the natural environment. It was able to grow photoheterotrophically under anaerobic light conditions and also chemoheterotrophically under aerobic dark conditions. Optimal growth occurred at $50{ }^{\circ} \mathrm{C}$ and pH 7·5-8.0. The cells contained bacteriochlorophyll (Bchl) $a$ and $\gamma$-carotene derivatives as photosynthetic pigments, but lacked Bchl $c$ and chlorosomes. Cellular fatty acids in the isolate were mainly C16:0, C14:0 and C15:0. The major quinone was menaquinone-11. The DNA G+C content was $62.0 \mathrm{~mol} \%$ (by HPLC). Phylogenetic analysis based on 16S rDNA sequencing suggested that the isolate belonged to the anoxygenic filamentous phototrophic bacteria represented by Chloroflexus aurantiacus, but was clearly distant from all members in this group (the sequence similarities between the isolate and its relatives were less than $83 \cdot 8 \%$ ). Based on genotypic and phenotypic data, the name Roseiflexus castenholzii gen. nov., sp. nov. is proposed for this isolate; the type strain is HLO8 $^{\mathrm{T}}$ (= DSM $13941^{\mathrm{T}}=\mathrm{JCM}^{11240^{\mathrm{T}}}$ ).
\end{abstract}

Keywords: Roseiflexus castenholzii, gen. nov., sp. nov., anoxygenic photosynthesis, thermophiles, bacterial mats, gliding motility

\section{INTRODUCTION}

The multicellular filamentous phototrophic bacterium Chloroflexus aurantiacus was first described by Pierson \& Castenholz (1974). Since this bacterium differed from the classical photosynthetic bacteria in many respects at the time, a new family of phototrophic bacteria was created for it (the family Chloroflexaceae; Trüper, 1976). Phylogenetic analysis based on $16 \mathrm{~S}$ rRNA gene sequence data revealed that the bacterium is not closely related to any other photosynthetic bacterium and forms the deepest branch among phototrophic bacteria (Oyaizu et al., 1987). The genus Chloroflexus, therefore, has received much attention as

Abbreviations: Bchl, bacteriochlorophyll; MK, menaquinone; RCR, Rabbit Creek Red.

The GenBank/EMBL/DDBJ accession number for the 16S rRNA gene sequence of strain $\mathrm{HLO}^{\top}$ is $\mathrm{AB} 041226$. a key organism in considering the origin of photosynthesis and the evolutionary process of photosynthetic systems. Another species, Chloroflexus aggregans, has been described in this genus (Hanada et al., 1995).

The group represented by Chloroflexus aurantiacus was named the anoxygenic filamentous phototrophs (Pierson \& Castenholz, 1995). This photosynthetic group includes some other genera: Oscillochloris (Keppen et al., 1994, 2000), Chloronema (Dubinina \& Gorlenko, 1975) and Heliothrix (Pierson et al., 1985). In addition, several Chloroflexus-like bacteria have been observed in marine environments (Pierson et al., 1994). Filamentous morphology and gliding motility are typical of these phototrophic bacteria, most of which possess light-harvesting apparatus called chlorosomes, which are intracellular vesicles containing bacteriochlorophyll (Bchl) $c$ or $d$. This notable photosynthetic apparatus is regarded as a typical 
feature in the anoxygenic filamentous phototrophs. An exception is Heliothrix oregonensis which has no chlorosomes. $H$. oregonensis is an interesting filamentous phototroph in that it contains Bchl $a$ as the sole chlorophyll species, but has not been cultured axenically. This bacterium was described as a coculture with the non-phototrophic bacterium, Isosphaera pallida (Pierson et al., 1985).

For several years, distinct red-coloured bacterial mats consisting of filamentous phototrophic bacteria have been found in several neutral to alkaline hot springs in Japan. These filaments contained Bchl $a$ and some carotenoids as photopigments, but no Bchl $c$ has been detected. Morphological and spectroscopic features resembled those of $H$. oregonensis. Similar bacterial mats have also been observed in hot springs in Yellowstone National Park (Boomer et al., 2000; Pierson \& Castenholz, 1995). However, filamentous bacteria like $H$. oregonensis have not been successfully isolated, despite of the endeavours of many researchers.

Recently, a distinct red-coloured bacterial mat developed in Nakabusa hot spring in Japan [M. Sugiura, M. Takano and K. Toda (all Nagoya University), S. Kawakami (Gifu University) and S. Hanada]. It was predominantly composed of a filamentous phototrophic bacterium containing Bchl $a$. The filamentous bacterium was isolated from the bacterial mat. The isolate, designated strain $\mathrm{HLO}^{\mathrm{T}}$, was a chlorosomeless, gliding, filamentous, phototrophic bacterium resembling $H$. oregonensis. In this paper, the distinct properties of strain $\mathrm{HLO}^{\mathrm{T}}$ are described and a new taxon is proposed for the isolate.

\section{METHODS}

Habitat and isolation. Strain $\mathrm{HLO}^{\mathrm{T}}$ was isolated from a bacterial mat in Nakabusa hot spring (Nagano Pref., Japan). The bacterial mat was well developed on a concrete wall in the outflow from the spring. The temperature and $\mathrm{pH}$ ranges of hot water in the site were $40-60{ }^{\circ} \mathrm{C}$ and $\mathrm{pH} 7 \cdot 8-8 \cdot 2$, respectively. The bacterial mat mainly consisted of three zonal layers predominantly formed by phototrophic bacteria. Each of the layers had a distinctive coloration (dark green, brown and red in colour). The surface of the mat was mainly occupied by dark green and brown coloured layers. The dark green layer was composed mainly of thermophilic cyanobacteria and the brown layer was due to Chloroflexus sp. In addition to these, there was a distinct red layer underneath the dark green and brown layers. The red layer was on the concrete wall with a thickness of less than $10 \mathrm{~mm}$. The red layer was mainly composed of a filamentous phototrophic bacterium with a diameter of $1 \mu \mathrm{m}$. The red layer contained Bchl $a$ and $\gamma$-carotene derivatives as photosynthetic pigments.

PE medium (Hanada et al., 1995) was used for isolation of strain $\mathrm{HLO}^{\mathrm{T}}$ from the red layer. The red layer collected from the hot spring was gently homogenized and inoculated onto a $1.5 \%$ agar-containing PE plate $(\mathrm{pH} 8 \cdot 0)$. The plate was incubated at $50{ }^{\circ} \mathrm{C}$ under anaerobic conditions in incandescent light $\left(30 \mathrm{~W} \mathrm{~m}^{-2}\right)$. Red to reddish-brown coloured colonies of strain $\mathrm{HLO}^{\mathrm{T}}$ were formed on the plate after a few weeks. Enrichment of pure cultures was established using the same medium $(\mathrm{pH} 7 \cdot 5)$ in screw-cap bottles at $50{ }^{\circ} \mathrm{C}$ under incandescent light $\left(30 \mathrm{~W} \mathrm{~m}^{-2}\right)$ or in flasks shaken vigorously (200 r.p.m.) in the dark at the same temperature. 02YE medium $(\mathrm{pH} 7 \cdot 5)$ was also used to culture the strain. This medium contained $\left(1^{-1}\right): 0 \cdot 2 \%$ yeast extract (Difco), $0.38 \mathrm{~g} \mathrm{KH}_{2} \mathrm{PO}_{4}, 0.39 \mathrm{~g} \mathrm{~K} \mathrm{~K}_{2} \mathrm{HPO}_{4}, 0.5 \mathrm{~g}$ $\left(\mathrm{NH}_{4}\right)_{2} \mathrm{SO}_{4}, 1 \mathrm{ml}$ vitamin mixture and $5 \mathrm{ml}$ basal salt solution. The vitamin mixture and basal salt solution were the same as those used in PE medium (Hanada et al., 1995).

Morphology. The size, shape and ultrastructure of the cells were examined by phase-contrast microscopy and transmission electron microscopy. For transmission electron microscopy, a centrifuged cell pellet was fixed with $5 \%(\mathrm{v} / \mathrm{v})$ glutaraldehyde and $1 \%$ (v/v) osmium tetroxide. Ultrathin sections of the sample embedded in epoxy resin (Kushida, 1980) were prepared with a Reichert ultra-microtome. Samples were stained with uranyl acetate and lead citrate, and examined using a Hitachi H-7000 transmission electron microscope. Gliding motility was determined by microscopically observing 1 -week-old colonies on an agar plate

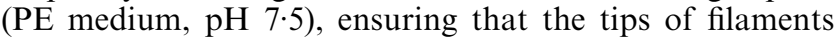
glided out.

Nutritional and physiological tests. For nutritional tests, $5 \mathrm{ml}$ medium containing one of various compounds as the sole carbon and energy source to a final concentration of $0 \cdot 25 \%(\mathrm{w} / \mathrm{v})$ was used in a multi-well plate (12 wells). The medium ( $\mathrm{pH} 7 \cdot 5$ ) basically contained $\left(1^{-1}\right): 0 \cdot 38 \mathrm{~g} \mathrm{KH} \mathrm{KO}_{4}$,

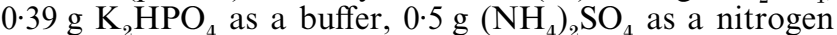
source, $1 \mathrm{ml}$ vitamin mixture and $5 \mathrm{ml}$ basal salt solution (see above). The following 18 compounds were used for the test: aspartate, glutamate, glycine, acetate, butyrate, citrate, malate, pyruvate, succinate, glucose, mannose, ethanol, glycerol, lactate, methanol, mannitol, Casamino acids and yeast extract. All organic carbon sources were neutralized and sterilized before addition. Each plate was incubated at $50{ }^{\circ} \mathrm{C}$ under the following three conditions: anaerobically in the light, anaerobically in the dark and aerobically in the dark. Anaerobic conditions were achieved with an AneroPack system (Mitsubishi Gas Chemical). Photoautotrophic growth was tested with $\mathrm{NaHCO}_{3}(50 \mathrm{mM})$ as a carbon source and $\mathrm{Na}_{2} \mathrm{~S} \cdot 9 \mathrm{H}_{2} \mathrm{O}(0 \cdot 2$ or $0.4 \mathrm{mM})$ or $\mathrm{Na}_{2} \mathrm{~S}_{2} \mathrm{O}_{3}$ $(3 \mathrm{mM})$ as electron donor. The results (OD at $660 \mathrm{~nm})$ were recorded after 1 week incubation. For estimation of the optimal temperature range for growth, the isolate was aerobically cultured in $\mathrm{PE}$ medium $(\mathrm{pH} 7 \cdot 5)$ at the following temperatures: $35,40,45,50,55,60$ and $65^{\circ} \mathrm{C}$. Growth at various $\mathrm{pH}$ values was also determined at $50{ }^{\circ} \mathrm{C}$ in $\mathrm{PE}$ medium that was buffered by $10 \mathrm{mM}$ potassium phosphate buffer ( $\mathrm{pH} 6,7$ and 8 ) or $10 \mathrm{mM}$ sodium glycine buffer ( $\mathrm{pH}$ 9 and 10$)$.

Spectroscopy and pigment analyses. Cells were collected from 1-week-old cultures in 02YE medium and were washed and disrupted by sonication $(140 \mathrm{~W}, 3 \mathrm{~min})$ in potassium phosphate buffer $\left(100 \mathrm{mM} \mathrm{KCl}, 3 \mathrm{mM} \mathrm{KH}_{2} \mathrm{PO}_{4}\right.$ and $2 \mathrm{mM}$ $\mathrm{K}_{2} \mathrm{HPO}_{4}$, pH 7.0). Absorption spectra of ultrasonically disrupted cells and chloroform/methanol $(2: 1, \mathrm{v} / \mathrm{v})$ extract were recorded with a Beckman DU 640 spectrophotometer. Pigments were extracted with acetone/methanol $(7: 2, \mathrm{v} / \mathrm{v})$ and analysed by HPLC equipped with a $\mu$ Bondapak C18 column $(8 \times 100 \mathrm{~mm}, \mathrm{RCM}$ type; Waters $)$ with methanol as a mobile phase (Takaichi \& Shimada, 1992).

Quinone and cellular fatty acid analyses. Quinones were extracted from freeze-dried cells with chloroform/methanol $(2: 1, \mathrm{v} / \mathrm{v})$ and $n$-hexane. The extract was purified with a Sep-Pak Plus cartridge (Waters) and analysed by HPLC 
equipped with a Zorbax ODS column $(4.6 \times 250 \mathrm{~mm}$; Shimadzu) for identification (Tamaoka et al., 1983).

Cellular fatty acids were converted to methyl esters by treatment with anhydrous methanolic $\mathrm{HCl}$. The methyl esters were analysed with a Hitachi M7200A GC/3DQMS system equipped with a DB-5ms capillary column (30 m $\times 0.25 \mathrm{~mm} ; \mathrm{J} \& \mathrm{~W}$ Scientific) coated with (5\%-phenyl)methylpolysiloxane (250 $\mathrm{nm}$ thickness). Helium was used as carrier gas at a flow rate of $1.5 \mathrm{ml} \mathrm{min}{ }^{-1}$. The column temperature profile was initially $100^{\circ} \mathrm{C}$ for $1 \mathrm{~min}$, then increased to $280{ }^{\circ} \mathrm{C}$ at a rate of $18{ }^{\circ} \mathrm{C} \mathrm{min}^{-1}$ and was finally held at $280{ }^{\circ} \mathrm{C}$ for $12 \mathrm{~min}$.

DNA base composition and 16S rDNA analyses. The total DNA of strain $\mathrm{HLO}^{\mathrm{T}}$ was extracted according to a previously described method (Kamagata \& Mikami, 1991) and digested with P1 nuclease using a GC kit (Yamasa Shoyu). The $\mathrm{G}+\mathrm{C}$ content was measured with a Shimadzu model LC-6A HPLC system equipped with a CLC-ODS column $(6 \times 150 \mathrm{~mm}$; Shimadzu $)$.

The 16S rRNA gene (16S rDNA) fragment was amplified by PCR (Hiraishi, 1992; Hiraishi et al., 1994) and sequenced directly with a dRhodamine dye terminator cycle sequencing kit (Applied Biosystems) and a model ABI 310 DNA sequencer. The obtained sequence and reference sequences were aligned and compared using the program CLUSTAL $\mathrm{W}$, version 1.6 (Thompson et al., 1994). The phylogenetic tree was constructed from the evolutionary distance matrix calculated by the neighbour-joining method (Saitou \& Nei, 1987) with Kimura's two-parameter (Kimura, 1980). Neighbour-joining analysis was performed with the MEGA program (Kumar et al., 1994). All gaps in the alignment were excluded to draw the tree.

\section{RESULTS AND DISCUSSION}

\section{Morphology and photosynthetic pigments}

The strain, designated strain $\mathrm{HLO}^{\mathrm{T}}$, was isolated from the red-coloured bacterial mat in Nakabusa hot spring $\left(40-60^{\circ} \mathrm{C}\right)$. Colonies of the isolate formed on

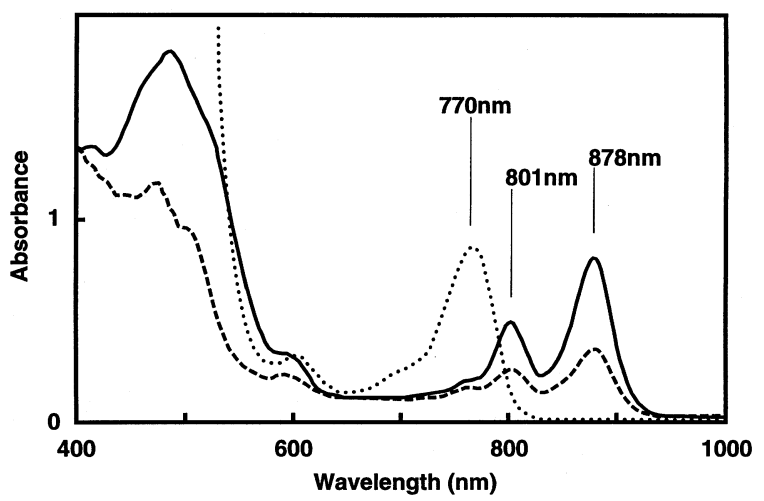

Fig. 2. Absorption spectra of ultrasonically disrupted strain $\mathrm{HLO}^{\top}$ cells grown under aerobic and dark (solid line) and anaerobic and light (broken line) conditions. The dotted line shows the spectrum of chloroform/methanol $(2: 1, \mathrm{v} / \mathrm{v})$ extract of the phototrophically grown cells. Spectra were recorded after 1 week incubation in 02 YE medium.

$1.5 \%$ agar plates (PE medium) were red to reddishbrown in colour and showed gliding motility. The isolate was an unbranched multicellular filamentous bacterium of indefinite length with a diameter of $0 \cdot 8-1 \cdot 0 \mu \mathrm{m}$ (Fig. 1, left). An electron micrograph of a thin section of the isolate revealed no evidence of intracellular vesicles or extensive internal membranes (Fig. 1, right).

Strain $\mathrm{HLO}^{\mathrm{T}}$ produced Bchls and the photosynthetic apparatus both under aerobic and anaerobic conditions. In vivo absorption spectra of ultrasonically disrupted cells (Fig. 2) grown aerobically (solid line) and anaerobically (broken line) showed two peaks (at 801 and $878 \mathrm{~nm}$ ) in the IR region that may be due to Bchl $a$. In addition, absorption maxima at 479 and
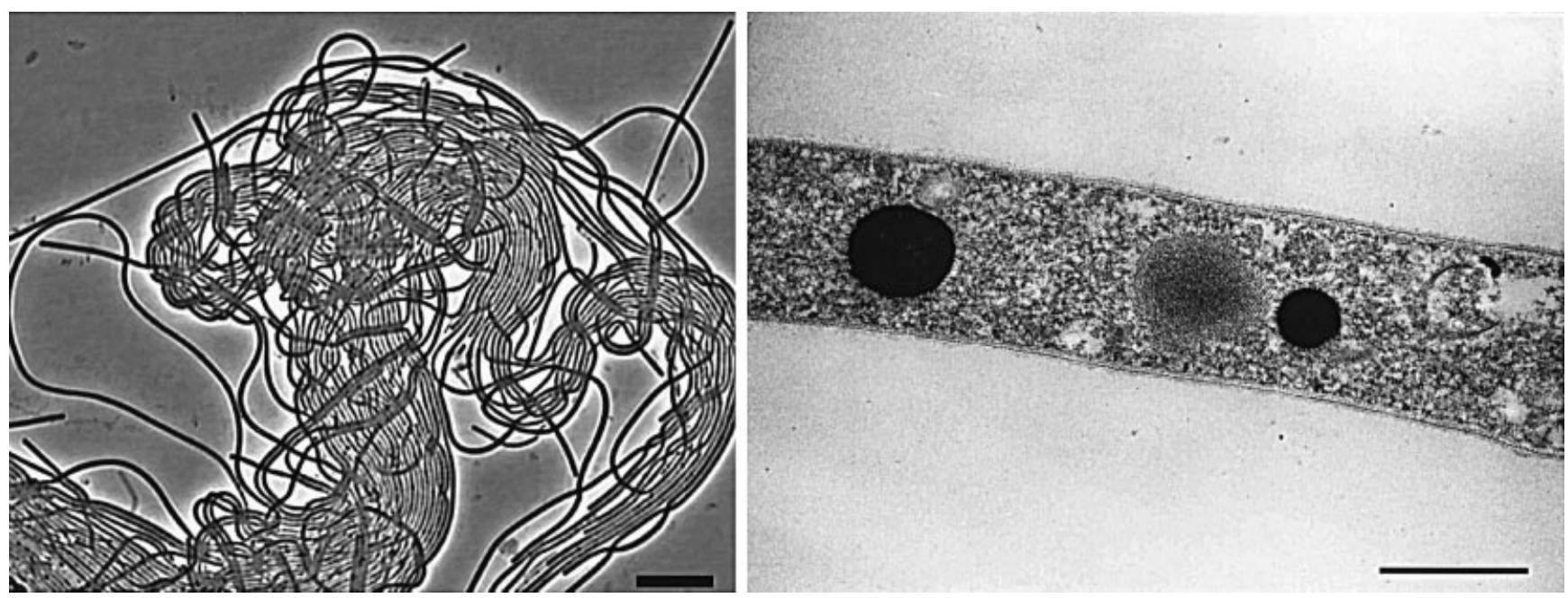

Fig. 1. Phase-contrast photomicrograph (left; bar, $10 \mu \mathrm{m}$ ) and electron micrograph of ultrathin section (right; bar, $0.5 \mu \mathrm{m})$ of strain $\mathrm{HLO}^{\top}$ cells. Both cells were anaerobically grown in PE medium under incandescent light $\left(30 \mathrm{~W} \mathrm{~m}^{-2}\right)$ for 1 week. 
Table 1. Phenotypic characteristics of strain $\mathrm{HLO}^{\top}$ and related anoxygenic filamentous phototrophic bacteria

Symbols: +, positive; - , negative; ND, not determined. Data were taken from the following references: Chloroflexus spp., Pierson \& Castenholz (1974) and Hanada et al. (1995); O. trichoides, Keppen et al. (2000); H. oregonensis, Pierson et al. (1984, 1985).

\begin{tabular}{|c|c|c|c|c|}
\hline Character & Strain HLO8 $^{\mathrm{T}}$ & Chloroflexus spp. & O. trichoides & H. oregonensis \\
\hline Morphology & Multicellular filaments & Multicellular filaments & Multicellular filaments & $\begin{array}{l}\text { Multicellular } \\
\text { filaments }\end{array}$ \\
\hline Cell diameter $(\mu \mathrm{m})$ & $0 \cdot 8-1 \cdot 0$ & $0 \cdot 5-1 \cdot 5$ & $1 \cdot 0-1 \cdot 5$ & $1 \cdot 5$ \\
\hline Gliding motility & + & + & + & + \\
\hline Metabolism & $\begin{array}{l}\text { Photoheterotroph, } \\
\mathrm{O}_{2} \text { respiration }\end{array}$ & $\begin{array}{c}\text { Photoheterotroph, } \\
\text { photoautotroph, } \\
\mathrm{O}_{2} \text { respiration }\end{array}$ & $\begin{array}{l}\text { Photoautotroph, } \\
\text { photoheterotroph }\end{array}$ & Photoheterotroph \\
\hline Optimal growth temp. $\left({ }^{\circ} \mathrm{C}\right)$ & 50 & 55 & $28-30$ & $40-55$ \\
\hline Bchl & $a$ & $a, c$ & $a, c$ & $a$ \\
\hline Chlorosomes & - & + & + & - \\
\hline $\begin{array}{l}\text { Peaks (nm) of in vivo } \\
\text { spectrum (near IR) }\end{array}$ & 878,801 & $868,808,740$ & 852,748 & 865,795 \\
\hline Major cellular fatty acids & $\begin{array}{l}\text { C16:0, } \\
\text { C14:0, } \\
\text { C15:0 }\end{array}$ & $\begin{array}{l}\text { C18:0, } \\
\text { C16:0, } \\
\text { C18: } 1\end{array}$ & $\begin{array}{l}\text { C18:1, } \\
\text { C16:0, } \\
\text { C16:1 }\end{array}$ & ND \\
\hline Major quinone & MK-11 & MK-10 & MK-10 & ND \\
\hline DNA G $+\mathrm{C}$ content $(\mathrm{mol} \%)$ & $62 \cdot 0$ & $56 \cdot 7-57 \cdot 1$ & $59 \cdot 2$ & ND \\
\hline
\end{tabular}

$590 \mathrm{~nm}$ were observed, but both spectra lacked a peak around $740 \mathrm{~nm}(\mathrm{Bchl} c)$ that is typical of Chloroflexus species. The spectrum of the chloroform/methanol extract (dotted line; Fig. 2) indicated a peak at $770 \mathrm{~nm}$ of Bchl $a$. No peak at $670 \mathrm{~nm}$ (due to $\mathrm{Bchl} c$ ) was found in the spectrum. Analysis of photopigments by HPLC clearly revealed the presence of Bchl $a$ and the absence of Bchl $c$ (data not shown). These findings suggest that the isolate has no chlorosomes (the light-harvesting apparatus containing $\mathrm{Bchl} c$ ).

In morphological and spectroscopic respects, the newly isolated phototrophic bacterium resembled other anoxygenic filamentous phototrophs, including Chloroflexus spp. and its relatives. However, the isolate lacked the light-harvesting apparatus (chlorosome), whereas almost all phototrophic members in the group, i.e. Chloroflexus spp. (Pierson \& Castenholz, 1974; Hanada et al., 1995), Oscillochloris trichoides (Keppen et al., 2000) and Chloronema giganteum (Dubinina \& Gorlenko, 1975; Gorlenko, 1988), possess it as a notable feature. $H$. oregonensis is the sole chlorosome-lacking phototroph in the group (Pierson et al., 1985). The new isolate, therefore, resembles $H$. oregonensis in lacking the distinct light-harvesting system. There is, however, an obvious difference in the absorption spectra of the near-IR region between the present isolate and $H$. oregonensis. The in vivo absorption spectrum of the isolate had distinct peaks at 878 and $801 \mathrm{~nm}$ due to $\mathrm{Bchl} a$ probably bound to membranous proteins. Those of $H$. oregonensis were slightly blue-shifted (peaks were at 865 and $795 \mathrm{~nm}$ ). Strain HLO $^{\mathrm{T}}$ also contained novel $\gamma$-carotene derivatives (including their glycoside esters) as the caro- tenoids (identification of these carotenoids is under way).

\section{Physiological properties}

Strain HLO $^{\mathrm{T}}$ was able to grow photoheterotrophically under anaerobic conditions in the light and chemoheterotrophically under aerobic conditions in the dark. Yeast extract was a good substrate for growth under both aerobic and anaerobic conditions. Citrate, lactate, glucose and Casamino acids were utilized as a sole carbon source only under anaerobic light conditions; however, cell yields were clearly less than that obtained with yeast extract. The other simple organic compounds, i.e. acetate, butyrate, malate, pyruvate, succinate, aspartate, glutamate, glycine, mannose, ethanol, glycerol and mannitol, as sole energy sources did not support growth of the isolate under aerobic or anaerobic conditions. For determination of photoautotrophic growth with bicarbonate as sole carbon source, $\mathrm{Na}_{2} \mathrm{~S} \cdot 9 \mathrm{H}_{2} \mathrm{O}(0 \cdot 2$ or $0 \cdot 4 \mathrm{mM})$ or $\mathrm{Na}_{2} \mathrm{~S}_{2} \mathrm{O}_{3}(3 \mathrm{mM})$ were used as electron donors; the isolate did not show photoautotrophic ability under these conditions. No fermentative growth with glucose, yeast extract, Casamino acids or several other simple organic carbon sources was observed. Optimal growth occurred at $50^{\circ} \mathrm{C}$ and at $\mathrm{pH} 7 \cdot 5-8.0$ under photoheterotrophic or chemoheterotrophic conditions. Good growth occurred at $45-55^{\circ} \mathrm{C}$. Growth did not occur above $60{ }^{\circ} \mathrm{C}$ and no practical growth was observed below $40{ }^{\circ} \mathrm{C}$. The isolate grew between $\mathrm{pH}$ 6.0 and 9.0 and did not grow below pH 5.5 or above $\mathrm{pH} 9 \cdot 5$. 


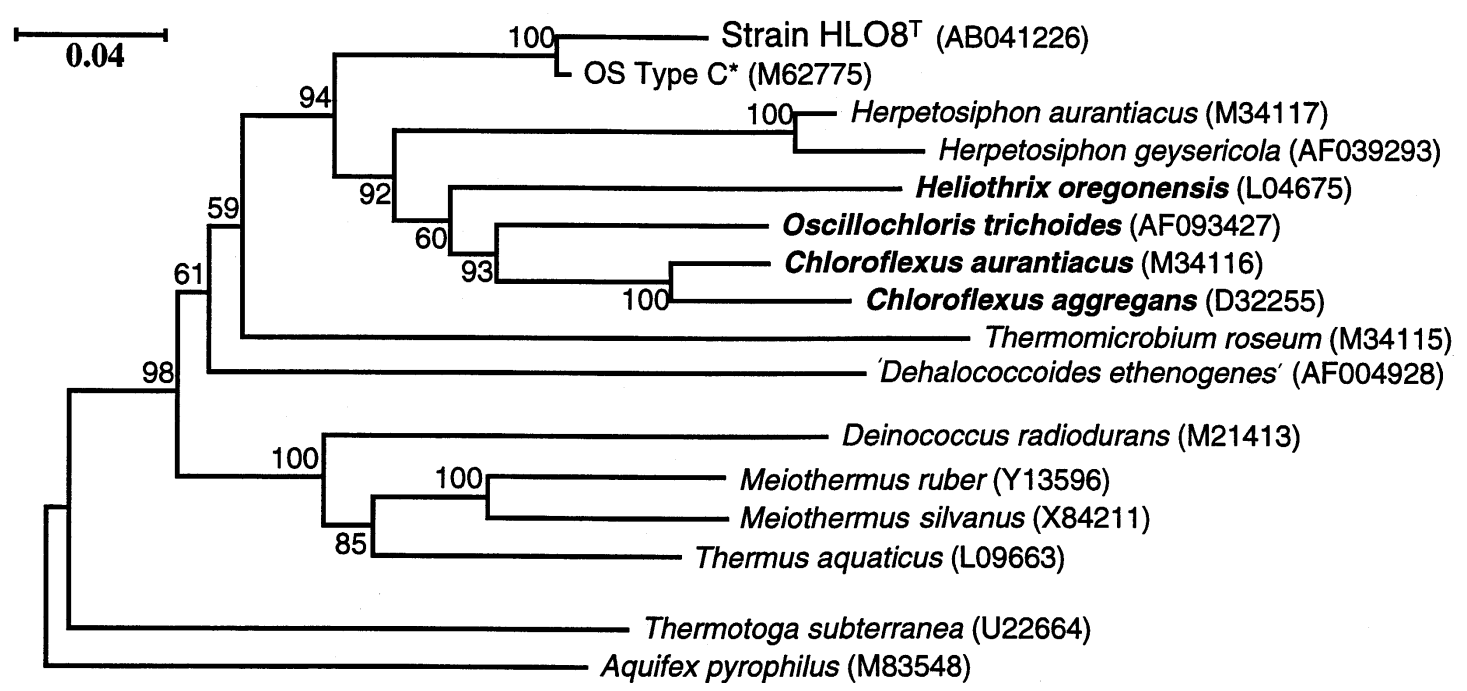

Fig. 3. Phylogenetic tree showing the relationship between strain $\mathrm{HLO}^{\top}$ and related species based on their $16 \mathrm{~S}$ rDNA sequence. Species given in bold represent members of the anoxygenic filamentous phototrophic bacteria. Bootstrap confidence values from 100 bootstrap replicates are indicated at the branching points. Bar, $4 \mathrm{nt}$ substitutions in $100 \mathrm{nt}$ in 165 rDNA sequences. The accession number of each reference species is shown in parentheses. OS Type $C$ (indicated by an asterisk) is a clone sequence retrieved from bacterial mats in Yellowstone by Weller et al. (1992).

\section{Other chemotaxonomic characteristics}

The major quinones, composition of cellular fatty acids and genomic $\mathrm{G}+\mathrm{C}$ content of the isolate were analysed. These results are summarized in Table 1, along with phenotypic characteristics of Chloroflexus species and its relatives. The predominant quinone of the isolate was menaquinone (MK)-11. Cellular fatty acids in the isolate were composed of C16:0 $(69 \cdot 5 \%$ of total fatty acids), C14:0 (19.9\%), C15:0 (5.8\%), C17: $0(1.8 \%)$, iso-C17:0 $(1.6 \%)$, iso-C18:0 $(0.8 \%)$ and iso-C16:0 (0.6\%). Unsaturated fatty acids, e.g. C18:1 or $\mathrm{C} 16: 1$, were not detected. The $\mathrm{G}+\mathrm{C}$ content of strain $\mathrm{HLO}^{\mathrm{T}}$ determined by HPLC was $62.0 \mathrm{~mol} \%$.

Results of chemotaxonomic analyses also suggested differentiation of strain $\mathrm{HLO}^{\mathrm{T}}$ from related species (Table 1). The isolate contained MK-11 as the major quinone, whereas MK-10 was the predominant quinone in Chloroflexus spp. and O. trichoides. Cellular fatty acids of the isolate were entirely saturated, whereas the other members contained unsaturated fatty acids such as C18:1. The isolate also contained small amounts of iso-branched fatty acids that have not been detected in its relatives. The genomic $\mathrm{G}+\mathrm{C}$ content of the isolate was $62.0 \mathrm{~mol} \%$, which was slightly higher than the $\mathrm{G}+\mathrm{C}$ contents of its relatives (less than $60 \mathrm{~mol} \%$ in Chloroflexus spp. and $O$. trichoides).

\section{Phylogenetic position}

Phylogenetic analysis based on 16S rDNA sequence showed that strain $\mathrm{HLO}^{\mathrm{T}}$ was related to the anoxygenic filamentous phototrophs (Fig. 3). The most closely related sequence to that of strain $\mathrm{HLO}^{\mathrm{T}}$ was that of 'OS type C', which was not a sequence of an isolated strain but a $16 \mathrm{~S}$ rDNA clone retrieved from Octopus Spring in Yellowstone (Weller et al., 1992). The sequence similarity was significantly high $(95 \cdot 7 \%$; the compared length was $1087 \mathrm{bp}$ ).

The position of the isolate was, however, certainly distant from other members of this group. The sequence similarities between the isolate and its related species were follows: Chloroflexus aurantiacus, $83.2 \%$ (the length compared in pairs was $1343 \mathrm{bp}$ ); Chloroflexus aggregans, 82.1\% (1356 bp); O. trichoides, $83.8 \%$ (1375 bp); and H. oregonensis, $78.6 \%$ (868 bp). The sequence similarities to these authentic species were less than $83.2 \%$ and values were low enough for creation of a new genus for in this group (Stackebrandt \& Goebel, 1994).

Several phenotypic properties of strain $\mathrm{HLO}^{\mathrm{T}}$ also supported the creation of a new taxon. There were obvious differences in in vivo spectra of the near-IR region between the present isolate and its relatives. The in vivo absorption spectrum of the isolate had distinct peaks at 878 and $801 \mathrm{~nm}$ due to Bchl $a$, probably bound to membranous proteins. Peaks in the absorption spectrum of $H$. oregonensis were slightly blueshifted (peaks at 865 and $795 \mathrm{~nm}$ ). In Chloroflexus spp., peaks were at 868 and $808 \mathrm{~nm}$, with a prominent peak at $740 \mathrm{~nm}$ that was due to Bchl $c$ (chlorosome). $O$. trichoides had peaks at 852 and $748 \mathrm{~nm}$ caused by Bchl $a$ and $c$, respectively. Chlorosomes in the genus Chloronema contained Bchl $d$ instead of Bchl $c$ and showed an absorption peak at $720 \mathrm{~nm}$ (data for the genus Chloronema not shown in Table 1; Dubinina \& Gorlenko, 1975; Gorlenko, 1988). 
The following phenotypic findings also suggested differentiating strain $\mathrm{HLO}^{\mathrm{T}}$ from related species: (1) strain HLO $^{\mathrm{T}}$ contained no chlorosome, a typical feature of most Chloroflexus spp. and relatives; (2) the isolate contained MK-11 as a major quinone; (3) cellular fatty acids of the isolate were entirely saturated, whereas related species contained significant amounts of unsaturated fatty acids; (4) the genomic $\mathrm{G}+\mathrm{C}$ content of the isolate was $62.0 \mathrm{~mol} \%$, which was slightly higher than values for related species (less than $60 \mathrm{~mol} \%$ ). Based on these genotypic and phenotypic characteristics, the name Roseiflexus castenholzii gen. nov., sp. nov. is proposed for the isolate.

\section{Distribution of chlorosome-less anoxygenic filamentous phototrophic bacteria}

Strain HLO ${ }^{\mathrm{T}}$ formed a distinct red-coloured dense bacterial mat in the natural environment (Nakabusa hot spring in Japan). Similar red-coloured mats have been observed in other Japanese hot springs such as Meotobuchi (Tochigi Pref.; $57^{\circ} \mathrm{C}, \mathrm{pH}$ 6.8) and Atagawa (Shidzuoka Pref.; $44^{\circ} \mathrm{C}, \mathrm{pH} 8 \cdot 0$ ) hot springs. Both mats mainly consisted of filamentous bacteria like $\mathrm{HLO}^{\mathrm{T}}$ and had the same spectroscopic properties, showing peaks at 878 and $801 \mathrm{~nm}$ in the IR region of their in vivo spectra and the absence of a peak around $740 \mathrm{~nm}$ (Bchl c). Morphological and spectroscopic properties suggest that HLO $8^{\mathrm{T}}$ or a bacterium closely related to it also inhabit these two hot springs. Isolation of these strains is being attempted, but has not yet been achieved.

Boomer et al. (2000) recently reported on red-coloured mats in the alkaline hot springs of Yellowstone National Park. Filaments found in the mat were designated Rabbit Creek Red (RCR). The RCR filament seems to be similar to $\mathrm{HLO}^{\mathrm{T}}$, but the following differences were noticed between these two bacteria: the diameter of the RCR filament was $1 \cdot 0-1.5 \mu \mathrm{m}$, wider than that of $\mathrm{HLO}^{\mathrm{T}}$; the cells of the filament were packed with stacked internal membranes; and the peaks in the IR region were clearly redshifted (peaks at 913 and $807 \mathrm{~nm}$ ). These differences suggest that the RCR filament is not the same species as $\mathrm{HLO}^{\mathrm{T}}$, but a novel species related to it. The chlorosome-less, anoxygenic, filamentous, phototrophic bacteria, like $\mathrm{HLO}^{\mathrm{T}}$, appear to be widespread in many hot springs in the world.

\section{Description of Roseiflexus gen. nov.}

Roseiflexus (ro.se.i.flex'us. L. adj. roseus rosecoloured; L. masc. n. flexus a bending, turning; N.L. masc. n. Roseiflexus rose-coloured bending).

Cells are unbranched, multicellular filaments showing gliding motility. Gram-negative. Bchl $a$ and $\gamma$-carotene derivatives are present. Chlorosomes and Bchl $c$ are absent. Cultures are red to reddish-brown in colour. Thermophilic, facultative phototroph that grows at $45-55^{\circ} \mathrm{C}$ and $\mathrm{pH} 7-9$. Aerobic/dark growth occurs at full atmospheric oxygen tension. Neither photoautotrophic nor fermentative growth is observed. Major quinone is $\mathrm{MK}-11$. Cellular fatty acids are entirely saturated, e.g. C14:0, C15:0 and C16:0. DNA G+C content is $62.0 \mathrm{~mol} \%$ (by HPLC). Phylogenetic position is in the green, non-sulfur bacteria represented by Chloroflexus aurantiacus. Type species is Roseiflexus castenholzii.

\section{Description of Roseiflexus castenholzii sp. nov.}

Roseiflexus castenholzii (cas.ten.holz'i.i. N.L. gen. n. castenholzii of Castenholz, named after Richard W. Castenholz, an American microbiologist who notably contributed to our knowledge of thermophilic filamentous phototrophs).

Basic phenotypic characteristics are the same as those described for the genus. Filamentous bacterium of indefinite length with a diameter of $0 \cdot 8-1 \cdot 0 \mu \mathrm{m}$. Neither chlorosomes nor intracytoplasmic membranes are present. Optimum photoheterotrophic and chemoheterotrophic growth occurs at $50{ }^{\circ} \mathrm{C}$ and $\mathrm{pH} 7 \cdot 5-8 \cdot 0$. Yeast extract is a good carbon source for growth. Citrate and glucose are utilized as sole energy source only under phototrophic conditions. Photopigments are $\mathrm{Bchl} a$ and $\gamma$-carotene derivatives; cell suspensions show absorption maxima at 479, 590, 801 and $878 \mathrm{~nm}$. Pigmentation occurs under both aerobic and anaerobic conditions. Cellular fatty acids consist of C16:0 (69.5\% total fatty acids), C14:0 (19.9\%) and C15:0 $(5 \cdot 8 \%)$. Unsaturated fatty acids are not detected. Small amounts of iso-branched fatty acids are detected. Major quinone is $\mathrm{MK}-11$. DNA $\mathrm{G}+\mathrm{C}$ content is $62.0 \mathrm{~mol} \%$ (by HPLC). Type strain is $\mathrm{HLO}^{\mathrm{T}}$ (= DSM $\left.13941^{\mathrm{T}}=\mathrm{JCM} 11240^{\mathrm{T}}\right)$.

\section{Note added in proof}

The identification of the carotenoids of this organism will be reported elsewhere (Takaichi et al., 2002).

\section{ACKNOWLEDGEMENTS}

We are very grateful to Miwa Sugiyama, Masao Takano and Katsumi Toda in Nagoya University and Shin-ichi Kawakami in Gifu University for information on the redcoloured bacterial mat and for the joint field investigations at Nakabusa hot spring. We thank the following researchers in the National Institute of Bioscience and Human-Technology: Xian Ying-Meng for transmission electron microscopy; Yasuyo Ashizawa for isoprenoid quinone and fatty acid analyses; Yoko Ueda for estimation of the DNA $\mathrm{G}+\mathrm{C}$ content; and Aiko Sukegawa for cultivation of the strain. We also thank Richard W. Castenholz in University of Oregon for his critical reading of the manuscript.

\section{REFERENCES}

Boomer, S. M., Pierson, B. K., Austinhirst, R. \& Castenholz, R. W. (2000). Characterization of novel bacteriochlorophyll- $a$-containing red filaments from alkaline hot springs in Yellowstone National Park. Arch Microbiol 174, 152-161. 
Dubinina, G. A. \& Gorlenko, V. M. (1975). New filamentous photosynthetic green bacteria containing gas vacuoles. Microbiology (English translation of Mikrobiologiya) 44, 452-458.

Hanada, S., Hiraishi, A., Shimada, K. \& Matsuura, K. (1995). Chloroflexus aggregans sp. nov., a filamentous phototrophic bacterium which forms dense cell aggregates by active gliding movement. Int J Syst Bacteriol 45, 676-681.

Hiraishi, A. (1992). Direct automated sequencing of 16S rDNA amplified by polymerase chain reaction from bacterial cultures without DNA purification. Lett Appl Microbiol 15, 210-213.

Hiraishi, A., Shin, Y. K., Ueda, Y. \& Sugiyama, J. (1994). Automated sequencing of PCR-amplified 16S rDNA on 'Hydrolink' gels. J Microbiol Methods 19, 145-154.

Kamagata, Y. \& Mikami, E. (1991). Isolation and characterization of a novel thermophilic Methanosaeta strain. Int J Syst Bacteriol 41, 191-196.

Keppen, O. I., Baulina, O. I. \& Kondratieva, E. N. (1994). Oscillochloris trichoides neotype strain DG-6. Photosynth Res 41, 29-33.

Keppen, O. I., Tourova, T. P., Kuznetsov, B. B., Ivanovsky, R. N. \& Gorlenko, V. M. (2000). Proposal of Oscillochloridaceae fam. nov. on the basis of a phylogenetic analysis of the filamentous anoxygenic phototrophic bacteria, and emended description of Oscillochloris and Oscillochloris trichoides in comparison with further new isolates. Int J Syst Evol Microbiol 50, 1529-1537.

Kimura, M. (1980). A simple method for estimating evolutionary rates of base substitutions through comparative studies of nucleotide sequences. J Mol Evol 16, 111-120.

Kumar, S., Tamura, K. \& Nei, M. (1994). MEGA: Molecular evolutionary genetics analysis software for microcomputers. Comput Appl Biosci 10, 189-191.

Kushida, H. (1980). An improved embedding method using ERL 4206 and Quetol 653. J Electron Microsc 29, 193-194.

Oyaizu, H., Debrunner-Vossbrinck, B., Mandelco, L., Studier, J. A. \& Woese, C. R. (1987). The green non-sulfur bacteria: a deep branching in the eubacterial line of descent. Syst Appl Microbiol 9, 47-53.

Pierson, B. K. \& Castenholz, R. W. (1974). A phototrophic gliding filamentous bacterium of hot springs, Chloroflexus aurantiacus, gen. and sp. nov. Arch Microbiol 100, 5-24.

Pierson, B. K. \& Castenholz, R. W. (1995). Taxonomy and physiology of filamentous anoxygenic phototrophs, In
Anoxygenic Photosynthetic Bacteria, pp. 31-47. Edited by R. E. Blankenship, M. T. Madigan \& C. E. Bauer. Dordrecht: Kluwer.

Pierson, B. K., Giovannoni, S. J. \& Castenholz, R. W. (1984). Physiological ecology of a gliding bacterium containing bacteriochlorophyll a. Appl Environ Microbiol 47, 576-584.

Pierson, B. K., Giovannoni, S. J., Stahl, D. A. \& Castenholz, R. W. (1985). Heliothrix oregonensis, gen. nov., sp. nov., a phototrophic filamentous gliding bacterium containing bacteriochlorophyll a. Arch Microbiol 142, 164-167.

Pierson, B. K., Valdez, D., Larsen, M., Morgan, E. \& Mack, E. E. (1994). Chloroflexus-like organisms from marine and hypersaline environments: distribution and diversity. Photosynth Res 41, 35-52.

Saitou, N. \& Nei, M. (1987). The neighbor-joining method: a new method for reconstructing phylogenetic trees. Mol Biol Evol 4, 406- 425.

Stackebrandt, E. \& Goebel, B. M. (1994). Taxonomic note: a place for DNA-DNA reassociation and $16 \mathrm{~S}$ rRNA sequence analysis in the present species definition in bacteriology. Int $J$ Syst Bacteriol 44, 846-849.

Takaichi, S. \& Shimada, K. (1992). Characterization of carotenoids in photosynthetic bacteria. Methods Enzymol 213, 374-385.

Takaichi, S., Maoka, T., Yamada, M., Matsuura, K., Haikawa, Y. \& Hanada, S. (2002). Absence of carotenes and presence of a tertiary methoxy group in a carotenoid from a thermophilic filamentous photosynthetic bacterium Roseiflexus castenholzii. Plant Cell Physiol (in press).

Tamaoka, J., Katayama-Fujimura, Y. \& Kuraishi, H. (1983). Analysis of bacterial menaquinone mixtures by high-performance liquid chromatography. J Appl Bacteriol 54, 31-36.

Thompson, J. D., Higgins, D. G. \& Gibson, T. J. (1994). CLUSTAL $\mathrm{W}$ : improving the sensitivity of progressive multiple sequence alignment through sequence weighting, position-specific gap penalties and weight matrix choice. Nucleic Acids Res 22, 4673-4680.

Trüper, H. G. (1976). Higher taxa of the phototrophic bacteria: Chloroflexaceae fam. nov. family for the gliding, filamentous, phototrophic green bacteria. Int J Syst Bacteriol 26, 74-75.

Weller, R., Bateson, M. M., Heimbuch, B. K., Kopczynski, E. D. \& Ward, D. M. (1992). Uncultivated cyanobacteria, Chloroflexuslike inhabitants, and spirochete-like inhabitants of a hot spring microbial mat. Appl Environ Microbiol 58, 3964-3969. 